\title{
Marital status and biological condition of Polish males
}

\author{
Anna Lipowicz \\ Institute of Anthropology, Polish Academy of Sciences, Kuźnicza 35, \\ 50-951 Wrocław, Poland; E-mail: anna.lipowicz@antro.pan.wroc.pl
}

\begin{abstract}
Strong evidence for marital differences in mortality has been demonstrated in a large number of countries. Married men and women have lower death rates than unmarried individuals within each adult age group. Additionally, married persons tend to be healthier as compared to unmarried. In the literature two explanations for this patterning have been proposed. 'The health selection hypothesis' suggested that disabled or less healthy people are not as likely to get married as the healthy ones. In 'the social causation hypothesis', marriage yields health benefits through emotional and social support which may act as a buffer against the effects of life stress. In this study, 'the social causation hypothesis' is supported.
\end{abstract}

KEY WORDS health, marriage, social support, physiological traits

Prz. Antropol. - Anthropol. Rev. (2001), vol. 64, pp. 81-91, Figs. 4, Table 1. ISBN 8386969-64-4, ISSN 0033-2003

\section{Introduction}

A strong evidence for marital differences in mortality has been repeatedly demonstrated in a large number of countries [TROVATO and LAURIS 1989; HU and GOLDMAN 1990; BRAJCZEWSKI and ROGUCKA 1993]. It has been found that death rates vary from highest to lowest as follows: divorced, widowed, never married and married. In every age-range married adults have lower mortality rates than unmarried males and females. This association exists even if various causes of death are analyzed [GOLDMAN 1993; ROGERS 1995; CHEUNG 1998].
Relatively little attention has been paid to the connection between marital status and various health indicators. First of all, scientists pointed to the conformity in marital differences in mortality and morbidity [VERBRUGGE 1979]. It is expected that groups with high mortality rates also have high morbidity rates. Furthermore, it is suggested that married people have higher self-related health rates than unmarried [WYKE and FORD 1992; IDLER and BENYAMINI 1997]. Similar findings are consistently reported for psychological well-being [MASTEKAASA 1992] and frequency of psychiatric disturbances [PRICE et al. 
1971; WARHEIT et al. 1976; HORWITZ et al. 1996].

In the literature two explanations for this patterning have been proposed. 'The health selection hypothesis' suggests that disabled or less healthy people are not as likely to get married as healthy people [KISKER and GOLDMAN 1987]. In such a situation marital status is dependent on health. Conversely, according to 'the social causation hypothesis' health status is seen to be dependent on marital status. It is assumed that marriage yields health benefits through emotional and social support, which may act as a buffer against the effects of life stress [WYKE and FORD 1992]. The fact of having a spouse (or family with children) may promote healthy lifestyle, for example, non-smoking behavior or alcohol-free lifestyle [UMBERSON 1987, 1992]. Marriage can also be considered as a substitute for formal health care [SOMERS 1979; VERBRUGGE 1979; LILLARD and PANIS 1996].

Using a case-control sample with married men as a control group, it has been studied (1) whether marital status influences the biological condition of Polish males and if so, (2) how this association changes with age.

\section{Materials and methods}

Data for this study come from medical archives of the Lower Silesian Medical Center and include 773 occupationally active men, inhabitants of Wrocław, Poland, who were examined in the course of health screening surveys conducted routinely since the early 1980s.

For the analysis the subjects were sampled from two educational groups: welleducated (men who had completed uni- versity education) and poorly-educated (men who had never passed beyond the level of basic vocational school). Basic vocational school in Poland is 2 or 3 years above primary schooling in some specific craft, e.g., mechanic, electrician, railwayman, etc. These two educational groups of adults are approximately equal to occupational categories: (1) professionals and (2) skilled/unskilled workers. For the purpose of the analysis, two age groups were chosen: younger men (25-30 years) and older ones (51-60 years).

For the purpose of the analysis ten biological characteristics were chosen. The BMI values and \% fat by Crook's method [CROOK et al. 1966] described level of fatness. Relative vital capacity and forced expiratory volume in $1 \mathrm{~s}$ $\left(\mathrm{FEV}_{1}\right)$ described functions of respiratory system. Systolic and diastolic blood pressure and pulse rate characterized functions of cardiovascular system. Moreover, values of intraocular pressure in the right eye (IOP) and two biochemical characteristics (total cholesterol and glucose) were analyzed.

To evaluate the hypothesized relationship among marital status and biological condition a simple standardized Z-score scale in each age and educational group was used. It allows us to avoid different units of measures $\left(\mathrm{kg} / \mathrm{m}^{2}, \mathrm{ml}, \mathrm{mmHg}\right.$, etc.) and to compare all characteristics as a uniform set. To facilitate an interpretation, negative sloped variables were multiplied by $(-1)$. The results are presented in a graphic form. Statistical testing was done by t-Student's test. Additionally, the chi-square test was used to assess the significance of differences between frequencies of 'positive' and 'negative' values of characteristics in analyzed groups. 


\section{Results}

Table 1 shows the number of individuals in each age-, educational- and marital group. The results of comparisons based on marital status are presented in Figures 1-4. On the basis of an importance for health status, standardized values of analyzed characteristics were defined as biologically 'favorable' or biologically 'unfavorable'. In the case of measures of fatness, parameters of cardiovascular system, intraocular pressure (IOP), total cholesterol and glucose, positive values were assessed as biologically 'unfavorable'. Conversely, for the variables with negative linear trend with age (both characteristics of respiratory system) positive values were assessed as biologically 'favorable'. In such manner, biologically 'favorable' values of characteristics (e.g., lower blood pressure, higher parameters of respiratory system, lower level of total cholesterol) were situated on the left side of the profile, whereas biologically 'unfavorable' values of characteristics (e.g., higher blood pressure, lower parameters of respiratory system, higher level of total cholesterol) - on the right side.

At the 25-30 age range, marital status affected the biological condition, measured by a set of ten characteristics, only to a small degree among all men (see Figs. 1 and 2). The z-score values were situated within $\pm 0.1 \mathrm{SD}$. However, never married men revealed slightly worse values of parameters of cardiovascular and respiratory systems than their married counterparts. At the same time, married men were fatter and had higher levels of biochemical characteristics (total cholesterol and glucose) than never married ones.

Marital differences in the biological condition increased considerably over the next 25-30 years. Thus among 51-60 years old, well-educated men, in the never-married group majority of analyzed characteristics had biologically 'unfavorable' values (Fig. 3). The highest differences occurred in the diastolic blood pressure $(\mathrm{p}=0.05)$, systolic blood pressure and parameters of respiratory systems. The intraocular pressure (IOP) and level of fatness showed somewhat lower marital differences. But two biochemical parameters (total cholesterol and glucose) showed 'unfavorable' values for married men, whereas never married achieved better values of these parameters.

A similar pattern occurred among poorly-educated older men (Fig. 4). The comparison of biological profiles of two groups of 51-60 years old poorlyeducated men showed that in 8 out of the 10 analyzed characteristics, never married men achieved biologically 'unfavorable' values. They had significantly higher systolic and diastolic blood pressure, higher pulse rate $(\mathrm{p}=0.05)$, higher intraocular pressure $(p=0.01)$, lower relative vital capacity

Table 1. The number of individuals in each age-, educational-, and marital group

\begin{tabular}{|c|c|c|c|c|}
\hline \multirow[b]{2}{*}{ Category } & \multicolumn{2}{|c|}{$25-30$} & \multicolumn{2}{|c|}{$51-60$} \\
\hline & Never married & Currently married & Never married & Currently married \\
\hline Well-educated & 123 & 50 & 22 & 60 \\
\hline Poorly-educated & 268 & 100 & 33 & 117 \\
\hline Total & 391 & 150 & 55 & 177 \\
\hline
\end{tabular}




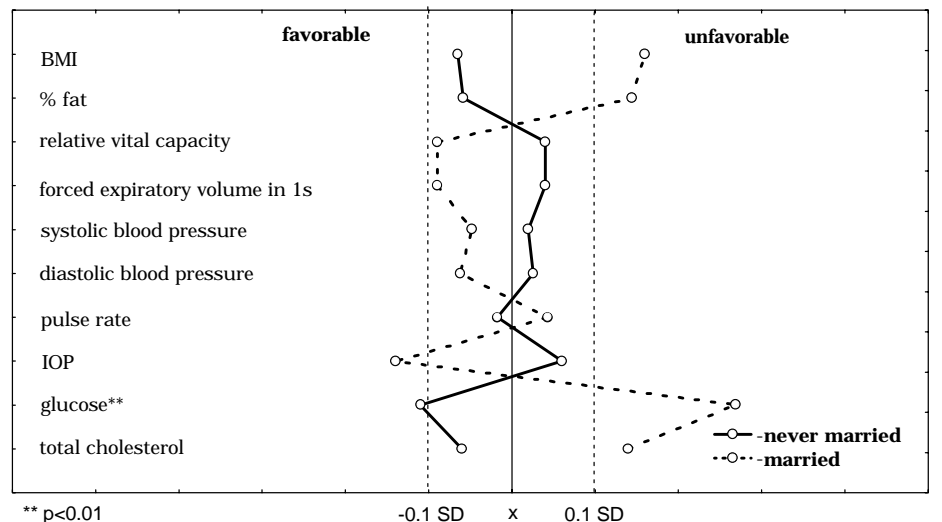

Fig. 1. The biological condition profile comparison of well-educated young men (25-30 yrs.) based on their marital status.

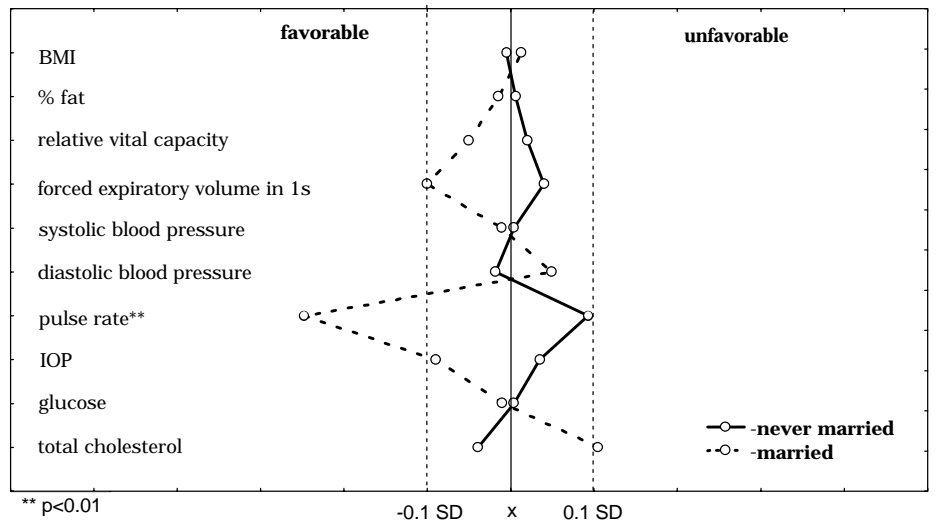

Fig. 2. The biological condition profile comparison of poorly-educated young men (25-30 yrs.) based on their marital status.

and forced expiratory volume in $1 \mathrm{~s}$ and higher glucose concentration (only BMI and total cholesterol showed 'favorable' values for never married men).

Although not all differences were statistically significant, but the trend seemed to be clear, thus the chi-square test was used to assess the significance of differences between frequencies of 'positive' and 'negative' values of characteristics in never married and married men in each age and educational group. We found that regardless of the educa- tional level, 25-30 years old married men did not differ from never married men in the frequency of 'positive' and 'negative' values of characteristics. However, 51-60 years old married men achieved 'positive' values of biological parameters more often as compared with never married men $(p=0.023$, for both educational groups). Generally, it can be concluded that regardless of the level of education, the biological condition of never married men seems to be worse when compared with married men. 


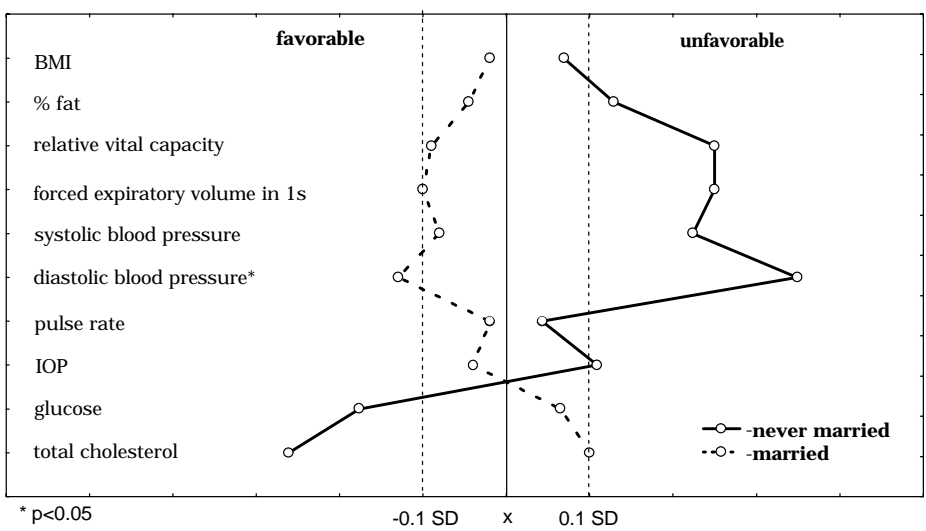

Fig. 3. The biological condition profile comparison of well-educated older men (51-60 yrs.) based on their marital status.

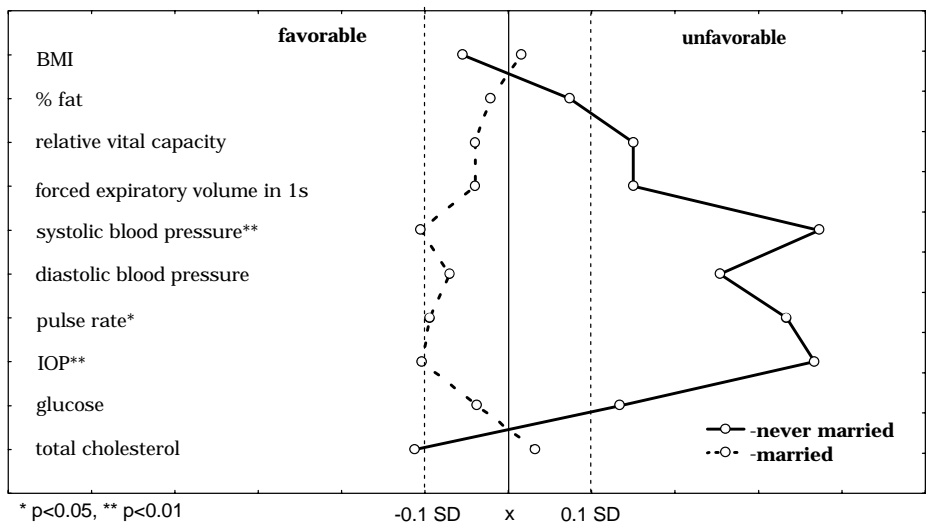

Fig. 4. The biological condition profile comparison of poorly-educated older men (51-60 yrs.) based on their marital status.

\section{Discussion}

In the literature, two processes are pointed out as a reason of health differences between marital status groups: selection mechanisms and social causation mechanisms. According to 'the health selection theory' the relatively better health status of married people is a result of the selection of healthy persons into marriage and leaving the un- healthy among single people. According to 'the social causation theory' marriage has a health protecting effect through factors such as social support, healthrelated behavior and material circumstances. The health selection theory and the social causation theory are not mutually exclusive and it is considered that a combination of selection and causal factors can produce the described marital differences in health status. This 
paper supports the social causation theory and supplies some evidence that marriage (especially marital seniority) plays a protective role for the health status of men.

In majority of epidemiological studies, social support is defined as a number of social contacts maintained by a person or the extensiveness of a social network [KAPLAN et al. 1993]. Other studies emphasized the perception of belonging to a social network of communication and mutual obligation [COBB 1976]. HEITZMANN and KAPLAN [1988] reviewed the literature and found 23 different measurement techniques of measuring social support's effects on health. One of the most often used and freely available measures is marital status. Most epidemiological studies concerning health-support outcome connection limited their observations to survival or mortality. It is shown that socially isolated people have lower longevity and more often suffer from diseases than people with wide social networks [HOUSE et al. 1982, 1988; WELIN et al. 1985; ROSENGREN et al. 1989; TROVATO and LAURIS 1989; MENDES DE LEON et al. 1992; ROGERS 1995; KAPRIO et al. 1996; WELON et al. 1999].

Empirical evidence concerning the relationship between social support and biological condition is rather scarce. It is commonly focused on marital differences in body mass and level of fatness. But the relationship between marital status and obesity is not clear. SOBAL et al. [1992] compared 10 studies from 5 countries published during the period from 1978 to 1991 and did not find any consistent relationship between fatness and marital status. Among men, 4 stud- ies showed that married people were fatter, 3 found no association, and 1 noted a curvilinear pattern. Similarly among women, 4 studies found that married women were fatter, 2 showed they were leaner, 2 found no relationship, and 2 had mixed associations [SOBAL et al. 1992]. In this study never married males were fatter in the 51-60 age group. On the other hand, based on data of more than 16000 Dutch men and women aged 25-74 years, JOUNG et al. [1995] found that married subjects showed the highest percentage of people with normal weight, compared with other marital statuses. Some evidence suggests, however, that there is no association between marital status and BMI values [ROSENGREN et al. 1989; WYKE and FORD 1992; GLIKSMAN et al. 1995].

It is difficult to distinguish a clear pattern of marital differences in concentrations of total cholesterol and glucose. This relationship is not consistent in both educational groups. Among welleducated men, married men achieved higher values of cholesterol and glucose than never married men. Among poorlyeducated men, analyzed parameters did not show a uniform tendency.

Marital status has been identified as one of the most important characteristics associated with coronary heart disease [VERBRUGGE 1979; VENTERS et al. 1986; ROSENGREN et al. 1989; MENDES DE LEON et al. 1992; GLIKSMAN et al. 1995]. This study shows that a relationship exists also between marital status and blood pressure. Older never married men from Wrocław had higher systolic and diastolic blood pressure. These findings conform to MENDES DE LEON et al.'s [1992] findings for 45-59 years old men from Rotterdam, where never 
married men had the highest average diastolic blood pressure $(83.0 \mathrm{mmHg})$, whereas married men - a significantly lower one $(79.9 \mathrm{mmHg}, \mathrm{p}<0.05)$. Similarly, GLIKSMAN et al. [1995] found that elderly Australian men living alone had the highest mean systolic blood pressure. But WYKE and FORD'S [1992] study of 55 years old Scottish men showed that only no longer married men had significantly higher systolic blood pressure than married men. Never married men had somewhat lower blood pressure than other marital groups.

Aside from higher blood pressure never married men from Wroclaw had higher pulse rates. It is consistent with VERBRUGGE's [1979] results, where American single people had higher values of all rates of heart conditions.

Stress (defined as the experience of stressful life events) is considered to influence the incidence of various psychological and physical illnesses. Stressful situations, anxiety, instability and feeling of social isolation are responsible for a poor condition of the cardiovascular system [VENTERS 1986]. The catecholamine system, stimulated by a stressful event, excretes the stress hormones (adrenaline and noradrenaline). These hormones play a major role in the functioning of the cardiovascular system. An individual under stress secretes more of these hormones which have the effect of increasing heart rate and blood pressure. Prolonged periods of increased blood pressure may lead to hypertension and other cardiovascular disease [KAPLAN et al. 1993]. SIEGRIST et al. [1982] found that $31 \%$ of patients post myocardial infarction were exposed to three or more "critical negative life events" and were chronically over- worked compared with $14 \%$ in the healthy group.

Marriage decreases level of stress. Only $14.7 \%$ of $47-55$ years old married men from Sweden reported permanent stress during the preceding five years, whereas $17.9 \%$ of never married men were severely stressed $(\mathrm{p}<0.05$; ROSENGREN et al. [1989]). Generally, married people are more likely to be happy than never married men and women. LEE et al. [1991] found that among 25-39 years old American men $46.8 \%$ married ones reported being very happy as compared with only $21.0 \%$ of never married ones. Findings of GLENN and WEAVER'S [1981] study indicate that marital happiness has a far greater contribution to global happiness than satisfaction with work, financial situation, family life, nonworking activities, friendships and health and physical condition. It appears that selective factors play an important role in the explanation of the above-described marital differences in happiness. However, a longitudinal study of HoRWITZ et al. [1996] showed that even taking into consideration premarital levels of depression and alcohol problems, married people were still less depressed than people who remained single.

The literature suggests that intraocular pressure (IOP) can be affected by the emotional state of individuals [GRIGNOLO et al. 1977; SEDDON et al. 1983; SHILY 1987; KALUZA et al. 1996; ERB et al. 1998]. ERB et al. [1998] found that both psychological and physical stress increase blood pressure, whereas only psychological stress increases intraocular pressure $(p=0.048)$. SEDDON et al. [1983] pointed at high income as a variable significantly asso- 
ciated with ocular hypertension. This study shows that an association exists between intraocular pressure and marital status. Never married men achieved higher values of IOP as compared with married men. It is assumed that prolonged stress is responsible for this relationship.

In this study relative vital capacity and forced expiratory volume in $1 \mathrm{~s}$ turned out to be dependent on marital status. Elderly never married men achieved lower values of both parameters of respiratory systems. BEN-SHLOMO et al. [1993] found a significant association between $\mathrm{FEV}_{1}$ and marital status among British men, where married individuals were characterized by the highest forced expiratory volume in $1 \mathrm{~s}$, whereas never married ones - the lowest. In contrast, WYKE and FORD [1992] analyzed data of 55 years old Scottish men and found that married men had worse values of respiratory parameters than never married men (these differences were nonsignificant).

In this study the biological condition of Polish males has proven to be associated with marital status. Never married men are in a worse biological condition measured by ten biological characteristics. Deterioration of the efficiency of body systems concerned especially never married men. Additionally, marital differences increase with age. It is assumed that a protective role of marriage (effect of marital seniority) is responsible for the above-described pattern.

\section{Final remarks}

A limitation of the present study is that, like many previous studies, the findings are restricted to men. Unfortu- nately, absence of female data in this material does not permit us to analyze gender differences in the biological condition by marital status. However, numerous studies suggest that the same pattern has emerged for both men and women. Reduced risk of mortality, better health status and better biological condition were noted among married people; though these benefits are greater for men than for women (HU and GOLDMAN 1990; ROGERS 1995).

Currently, modern societies face an enormous problem. The number of people living alone has increased rapidly. On the one hand, this results from the fact that people tend to get married at an increasingly later age as well as from a growing number of divorces. On the other hand, more people opt for living alone by choice. Additionally, economic problems, unemployment (especially among poorly educated part of society) and lack of state protection for maladjusted people have caused a reduction in marriage frequency [GLICK and LIN 1986; KIERNAN 1988]. Also among well-educated, careeroriented people a steady increase in the frequency of people postponing the decision about marriage till later has been observed. In turn, a comparison made by KAPLAN et al. [1993] showed that low social support (namely living alone, being unmarried, lack of relatives and friends) is a risk factor in cardiovascular disease (relative risk $\mathrm{RR}=1.70$ ), and that the strength of this risk factor is comparable to most other major risk factors such as cigarette smoking $(\mathrm{RR}=1.58-2.20)$, obesity $(\mathrm{RR}=1.20)$, LDL cholesterol $(\mathrm{RR}=1.51)$, alcohol consumption $(\mathrm{RR}=2.0)$ and physical activity $(\mathrm{RR}=1.40)$. 


\section{References}

Ben-Shlomo Y., G.D. Smith, M. Shipley, M.G. MARMOT, 1993, Magnitude and causes of mortality differences between married and unmarried men, J. Epidemiol. Community Hlth, 47, 200-205

BRAJCZEWSKi C., E. RogUCKA, 1993, Social class differences in rates of premature mortality among adults in the city of Wroctaw, Poland, Am. J. Hum. Biol., 5, 461-471

Cheung Y.-B., 1998, Accidents, assaults, and marital status, Soc. Sci. Med., 47, 1325-1329

CовB S., 1976, Social support as a moderator of life stress, Psychosomatic Medicine, 38, 300313

Crook G. H., C.A. Bennett, W.D. Noorwood, J.A. MAHAFFEY, 1966, Evaluation of skinfold measurements and weight chart to measure body fat, J. Am. Med. Assoc., 198, 157-162

ERB C., S. BROdY, H. RAU, 1998, Effect of mental and physical stress on intraocular pressure - a pilot study, Klin. Monatsbl. Augenheilkd., 212, 270-274

GlenN N.D., C.N. WeAVer, 1981, The contribution of marital happiness to global happiness, J. Mar. Family, 43, 161-168

GLICK P.C., S.-L. LIN, 1986, More young adults are living with their parents: who are they?, J. Mar. Family, 48, 107-112

Gliksman M.D., R. Lasarus, A. Wilson, S.R. LEEDER, 1995, Social support, marital status and living arrangement correlates of cardiovascular disease risk factors in the elderly, Soc. Sci. Med., 40, 811-814

GoldMAN N., 1993, The perils of single life in contemporary Japan, J. Mar. Family, 55, 191204

Grignolo F.M., C. Bongioanni, B.B. CARENini, 1977, Variations of intraocular pressure induced by psychological stress, Klin. Monatsbl. Augenheilkd., 170, 562-569

Heitzmann C.A., R.M. Kaplan 1988, Assessment of methods for measuring social support, Health Psychol., 7, 75-109

Horwitz A.V., H.R. White, S. Howell-White, 1996, Becoming married and mental health: a longitudinal study of a cohort of young adults, J. Mar. Family, 58, 895-907

House J.S., K.R. LANDIS, D. UMBERSON, 1988 , Social relationships and health, Science, 241, 540-545
House J.S., C. RobBins, H.L. Metzner, 1982, The association of social relationships and activities with mortality: prospective evidence from the Tecumseh Community Health Study, Am. J. Epidemiol., 116, 123-140

Hu Y., N. Goldman, 1990, Mortality differentials by marital status: an international comparison, Demography, 27, 233-250

IDLER E.L., Y. BENYAMINI, 1997, Self-rated health and mortality: a review of twenty-seven community studies, J. Hlth Soc. Behav., 38, 2137

Joung I.M.A., K. Stronks, H. van De MHeEn, J.P. MACKENBACH, 1995, Health behaviours explain part of the differences in self reported health associated with partner/marital status in The Netherlands, J. Epidemiol. Community Hlth, 49, 482-488

Kaluza G., I. Strempel, H. Maurer, 1996, Stress reactivity of intraocular pressure after relaxation training in open-angle glaucoma patients, J. Behav. Med., 19, 587-598

Kaplan R.M., J.F. SAllis JR., T.L. Patterson, 1993, Health and human behavior, McGrawHill Inc., New York

Kaprio J., S. Sarna, M. Fogelholm, M. KoskenvUO, 1996, Total and occupationally active life expectancies in relation to social class and marital status in men classified as healthy at 20 in Finland, J. Epidemiol. Community Hlth, 50, 653-660

KIERNAN K.E., 1988, Who remains celibate?, J. Biosoc. Sci., 20, 253-263

Kisker E.E., N. Goldman, 1987, Perils of single life and benefits of marriage, Soc. Biol., 34, $135-152$

Lee G.R., K. Seccombe, C.L. Shehan, 1991, Marital status and personal happiness: An analysis of trend data, J. Mar. Family, 53, 839844

LiLlard L.A., C.W.A. PANIS, 1996, Marital status and mortality: the role of health, Demography, 33, 313-327

MASTEKAASA A., 1992, Marriage and psychological well-being: some evidence on selection into marriage, J. Mar. Family, 54, 901-911

Mendes DE LeON C.F., A.W. Appels, F.W.J. Otten, E.G.W. Schouten, 1992, Risk of mortality and coronary heart disease by marital status in middle-aged men in the Netherlands, Inter. J. Epidemiol., 21, 460-466

Price J.S., E. Slater, E.H. HARE, 1971, Marital status of first admissions to psychiatric beds in 
England and Wales in 1965 and 1966, Soc. Biol., suppl. 18, 74-94

Rogers R.G., 1995, Marriage, sex, and mortality, J. Mar. Family, 57, 515-526

Rosengren A., H. Wedel, L. Wilhelmsen, 1989, Marital status and mortality in middleaged Swedish men, Am. J. Epidemiol., 129, 5464

Seddon J.M., B. Schwartz, G. Flowerdew, 1983, Case-control study of ocular hypertension, Arch. Ophtalmol., 101, 891-894

SHILY B.G., 1987, Psychophysiological stress, elevated intraocular pressure, and acute closed-angle glaucoma, Am. J. Optom. Physiol. Opt., 64, 866-870

SiEgRIST J., K.H. DitTMAN, K. RitTNER, I. WEBER, 1982, The social context of active distress in patients with early myocardial infarction, Soc. Sci. Med., 16, 443-454

Sobal J., B.S. Rauschenbach, E.A. Frongillo JR., 1992, Marital status, fatness and obesity, Soc. Sci. Med., 35, 915-923

SOMERS A.R., 1979, Marital status, health, and use of health services, J. Am. Med. Assoc., 241, 1818-1822

Trovato F., G. LAURIS, 1989, Marital status and mortality in Canada: 1951-1981, J. Mar. Family, 51, 907-922

UMBERSON D., 1987, Family status and health behaviors: social control as a dimension of social integration, J. Hlth Soc. Behav., 28, 306319
UMBERSON D., 1992, Gender, marital status and the social control of health behavior, Soc. Sci. Med., 34, 907-917

VENTERS M.H., 1986, Family life and cardiovascular risk: implications for the prevention of chronic disease, Soc. Sci. Med., 22, 1067-1074

Venters M., D.R. Jacobs JR., P. Pirie, R.V. Luepker, A.R. Folsom, R.F. Gillum, 1986, Marital status and cardiovascular risk: The Minnesota Heart Survey and the Minnesota Heart Health Program, Prev. Med., 15, 591605

VerbRUGGe L.M., 1979, Marital status and health, J. Mar. Family, 41, 267-285

Warheit G.J., C.E. Holzer, R.A. Bell, S.A. AREY, 1976, Sex, marital status, and mental health: a reappraisal, Social Forces, 55, 459470

Welin L., G. Svärdsudd, S. Ander-Peciva, G. TibBlin, B. TibBlin, B. LARSSON, L. Wilhelmsen, 1985, Prospective study of social influences on mortality, Lancet, April 20, 915-918

WelON Z., T. BIELICKI, E. RoguCKa, R. MALINA, 1999, The effects of education and marital status on premature mortality rates among urban adults in Poland, Am. J. Hum. Biol., 11, 397-403

WyKe S., G. Ford, 1992, Competing explanations for associations between marital status and health, Soc. Sci. Med., 34, 523-532

\section{Streszczenie}

Liczne badania przeprowadzane $w$ wielu krajach, zarówno rozwijających się, jak i rozwiniętych, wskazują na silną zależność wskaźników umieralności od stanu cywilnego. W każdym przedziale wieku, najniższymi wskaźnikami umieralności charakteryzują się żonaci i mężatki, wyższymi zaś osoby samotne. W celu wyjaśnienia tego zjawiska sformułowano dwie hipotezy. Pierwsza z hipotez dotyczy tzw. selektywnego doboru do małżeństwa, która zakłada, że osoby o gorszej kondycji zdrowotnej, zarówno fizycznej, jak i psychicznej, częściej pozostają samotne. Druga hipoteza dotyczy ochronnej roli, jaką pełni małżeństwo i rodzina poprzez udzielanie tzw. społecznego wsparcia.

Celem pracy jest zbadanie, czy stan cywilny mężczyzn wpływa na ich kondycję biologiczna, a jeżeli tak, to w jaki sposób zależność ta zmienia się wraz z wiekiem. Materiał stanowią dane pochodzące $\mathrm{z}$ archiwum Dolnośląskiego Centrum Diagnostyki Medycznej DOLMED we Wrocławiu i obejmujące informacje o kondycji biologicznej (BMI, procentowa zawartość tłuszczu w organizmie, relatywna pojemność płuc, 1-sek. pojemność życiowa płuc, skurczowe i rozkurczowe ciśnienie krwi, tętno, ciśnienie w gałce ocznej, poziom glukozy i cholesterolu całkowitego w surowicy krwi) 773 zdrowych mężczyzn, mieszkańców 
Wrocławia. Zbadano dwie homogeniczne ze względu na stan cywilny grupy mężczyzn, a mianowicie kawalerów i aktualnie żonatych, będących w dwóch grupach wiekowych: 25-30 lat oraz 51-60 lat. Ze względu na wykształcenie, badanych podzielono na dwie grupy: lepiej wykształconych (wykształcenie wyższe) oraz gorzej wykształconych (ukończona co najwyżej szkoła zawodowa). Liczebności mężczyzn w poszczególnych kategoriach wieku, stanu cywilnego i wykształcenia zawiera tabela 1. Przeprowadzona osobno w każdej klasie wieku i wykształcenia, standaryzacja wszystkich analizowanych cech, pozwoliła na uwolnienie się od różnorodnych jednostek miar poszczególnych cech $\left(\mathrm{kg} / \mathrm{m}^{2}, \mathrm{ml}, \mathrm{mmHg}\right.$, i innych) oraz porównanie cech, potraktowanych jako jednolity zespół opisujący ogólną kondycję biologiczną. Wartości standaryzowanych cech dla wybranych grup przedstawiono w postaci graficznej (rys. 1-4).

Standaryzowane wartości dziesięciu analizowanych cech, na podstawie ich znaczenia dla stanu zdrowia, określono jako biologicznie „korzystne” lub biologicznie „niekorzystne”. Wszystkie te cechy mają bowiem charakter wartościujący, tzn. można je przełożyć na skalę „lepszy/gorszy”. W przedziale wieku 25-30 lat, zarówno wśród mężczyzn z wykształceniem wyższym, jak i z wykształceniem co najwyżej zawodowym, stan cywilny w niewielkim stopniu wpływał różnicująco na kondycję biologiczną. Wraz z wiekiem natomiast narastały różnice w kondycji biologicznej pomiędzy kawalerami i mężczyznami żonatymi i to na niekorzyść kawalerów. Narastanie różnic z wiekiem jest efektem ochronnej roli małżeństwa (efekt stażu małżeńskiego). Ponadto można sądzić, że ochronna rola małżeństwa jest tym większa, im niższe jest wykształcenie badanych mężczyzn. 